\title{
APLIKASI GMP DALAM PRODUKSI GARAM KONSUMSI BERYODIUM
}

\author{
Oleh : \\ Nami Lestari ${ }^{1)}$
}

\begin{abstract}
The main objective of Good Manufacturing Practise (GMP) implementation is products with quality, nutrition and for all consumers. GMP implementation is guided by the regulation of health minister (SK. Menteri Kesehatan No. 23/MEN-KES/SKII/1978). This regulation explains specifically about a better control process for good industry. The important aspects for GMP implementation are location, building, equipment sanitation, material/ingredients, end products, material packaging, labeling, storage and maintenance. The aspects can be applied on consumption salt industries. By implementation GMP, production process have been done to consumption salt products that is in accordance with SNI $01-3556-2000$ requirements.
\end{abstract}

Key words : consumption salt products and GMP

\section{PENDAHULUAN}

aram merupakan bahan kebutuhan vital bagi masyarakat dan merupakan Tsalah satu dari sembilan kebutuhan pokok masyarakat Indonesia. Selain itu garam mempunyai kedudukan yang unik karena tidak ada barang substitusi lain untuk menggantikannya. Karena sifat yang khas ini, maka sejak jaman Hindia Belanda, pemerintah telah mengatur pembuatan dan penyaluran garam, terutama penambahan kalium iodat pada garam untuk konsumsi ( BPPI Semarang, 1985).

Dari material awal, yaitu garam kasar ( krosok), industri garam di Indonesia memproduksi berbagai jenis garam untuk memenuhi berbagai keperluan akan garam, yaitu untuk kebutuhan rumah tangga, industri, peternakan dan pertanian. Namun demikian, cukup banyak hambatan dan kendala dibidang industri garam di Indonesia. Hambatan berupa kualitas garam yang belum maksimal, ketidakstabilan harga garam, proses produksi masih tradisional, persaingan dengan produk luar negeri dan lain-lain. $\mathrm{Hal}$ ini perlu dibenahi dan disempurnakan hingga Industri Garam di Indonesia dapat memenuhi kebutuhan konsumen dengan mengenalkan produk garam yang memenuhi persyaratan ( Berita Agrokim, 2008).

Menurut Badan Standardisasi Nasional ( 2000 ), garam yang digunakan dalam produk makanan didefinisikan sebagai pangan yang komponen utamanya natrium klorida $(\mathrm{NaCl})$ dengan penambahan kalium iodat $\left(\mathrm{KIO}_{3}\right)$. Pemerintah mengatur proses produksi dan pemasaran/penyaluran produk garam konsumsi beryodium, terutama terkait penyemprotan kalium iodat untuk penanggulangan masalah GAKY ( Gangguan Akibat Kekurangan Yodium ).

Untuk melindungi keselamatan masyarakat umum. Pemerintah melalui SK. Menteri Perindustrian RI No. 24/M/SK/2/1995, Tentang Pengesahan serta penerapan SNI

*) Peneliti Baristand industri Samarinda 
dan Penggunaan Tanda SNI secara wajib terhadap 10 (sepuluh) macam produk Industri, mewajibkan Produk Garam Konsumsi Beryodium untuk menggunakan Tanda SNI sesuai SNI 01 - 3556 - 2000. Di samping itu pemerintah juga mengeluarkan Peraturan Menteri Perindustrian RI No. 42/M/IND/PER/I/2005 Tentang Pengolahan, Pengemasan dan Pelabelan Garam Beryodium. Maksud Permen Perindustrian tersebut adalah untuk mengatur pengendalian bahan dan produk garam konsumsi beryodium.

Untuk meningkatkan mutu produk dan melindungi keselamatan dan kesehatannya, industri pengolahan garam konsumsi beryodium sebaiknya menerapkan GMP ( Good Manufacturing Practices) atau Cara Produksi Makanan yang Baik. GMP telah menjadi pedoman bagi produsen makanan dan minuman melalui SK. Menteri Kesehatan No. 23/Men Kes/SK/1978.

GMP merupakan suatu pedoman cara memproduksi makanan dengan tujuan agar produsen memenuhi persyaratan-persyaratan yang telah ditentukan untuk menghasilkan produk makanan bermutu sesuai dengan tuntutan konsumen ( Thaher, 2005). Jika industri garam konsumsi beryodium mengaplikasikan GMP dalam produksinya, serta menerapkan sistem mutu untuk Penggunaan tanda SNI, dipastikan industri tersebut sekaligus memenuhi persyaratan produksi, persyaratan produk, persyaratan nilai dan persyaratan yang dikehendaki konsumen, baik domestik maupun internasional.

Oleh karena itu, tulisan ini akan membahas penerapan GMP dalam proses pengolahan garam konsumsi beryodium. Diharapkan dengan memperhatikan aspekaspek GMP seperti lokasi, bangunan, fasilitas sanitasi, alat produksi, bahan, proses pengolahan, produk akhir, higiene karyawan, bahan kemasan, lebel, penyimpanan dan pemeliharaan, proses produksi yang aman dilaksanakan untuk menghasilkan produk pangan dengan mutu yang diharapkan (Winarno, 2004).

\section{PROSES PENGOLAHAN GARAM KONSUMSI BERYODIUM}

Garam adalah senyawa mineral berbentuk kristal berwarna putih yang diperoleh dari cara penguapan air laut. Proses pertama yang dilakukan adalah proses pengolahan bahan baku dengan metode penguapan air laut. Prinsipnya menggunakan kristalisasi bertingkat yaitu menguapkan dengan bantuan panas matahari hingga didapat larutan jenuh kemudian dikristalisasi dalam proses akhir hingga didapat kristal garam. Selanjutnya kristal garam dikeringkan (dijemur) dibawah sinar matahari \pm 1 minggu (Prasetyo, dkk, 1997)

Garam yang di dalamnya terkandung senyawa kalium iodat (garam beryodium ) merupakan salah satu nutrisi penting yang harus dikonsumsi secara teratur oleh manusia. Jumlah garam yang harus dikonsumsi per hari untuk setiap orang \pm 9 gram. Untuk masyarakat di negara berkembang seperti Indonesia, selain untuk memenuhi nutrisi tubuh, konsumsi garam ditujukan juga untuk memenuhi kebutuhan tubuh akan yodium (Berita Agrokim, 2008)

Garam beryodium adalah garam konsumsi yang mengandung komponen utama Natrium Klorida ( $\mathrm{NaCl}$ ) minimal $94,7 \%$, air maksimum $7 \%$, dan Kalium lodat $\left(\mathrm{KIO}_{3}\right.$ ) sebanyak minimal $30 \mathrm{mg} / \mathrm{kg}$ serta senyawa-senyawa lain. Untuk pengadaan garam beryodium. Pemerintah menerbitkan Peraturan Menteri Perindustrian Republik Indonesia No. 42/M-IND/PER/I/2005 Tentang Pengolahan, Pengemasan dan Pelabelan Garam Beryodium. ( Sudibyo, 2008 ).

Menurut Peraturan tersebut, garam yang dapat diiodisasi wajib memenuhi persyaratan kualitas garam bahan baku sesuai SNI $01-4435-2000$ dapat dilihat pada Tabel 1. 
Tabel 1. Syarat Mutu Garam Bahan Baku Untuk Industri Garam Beryodium *)

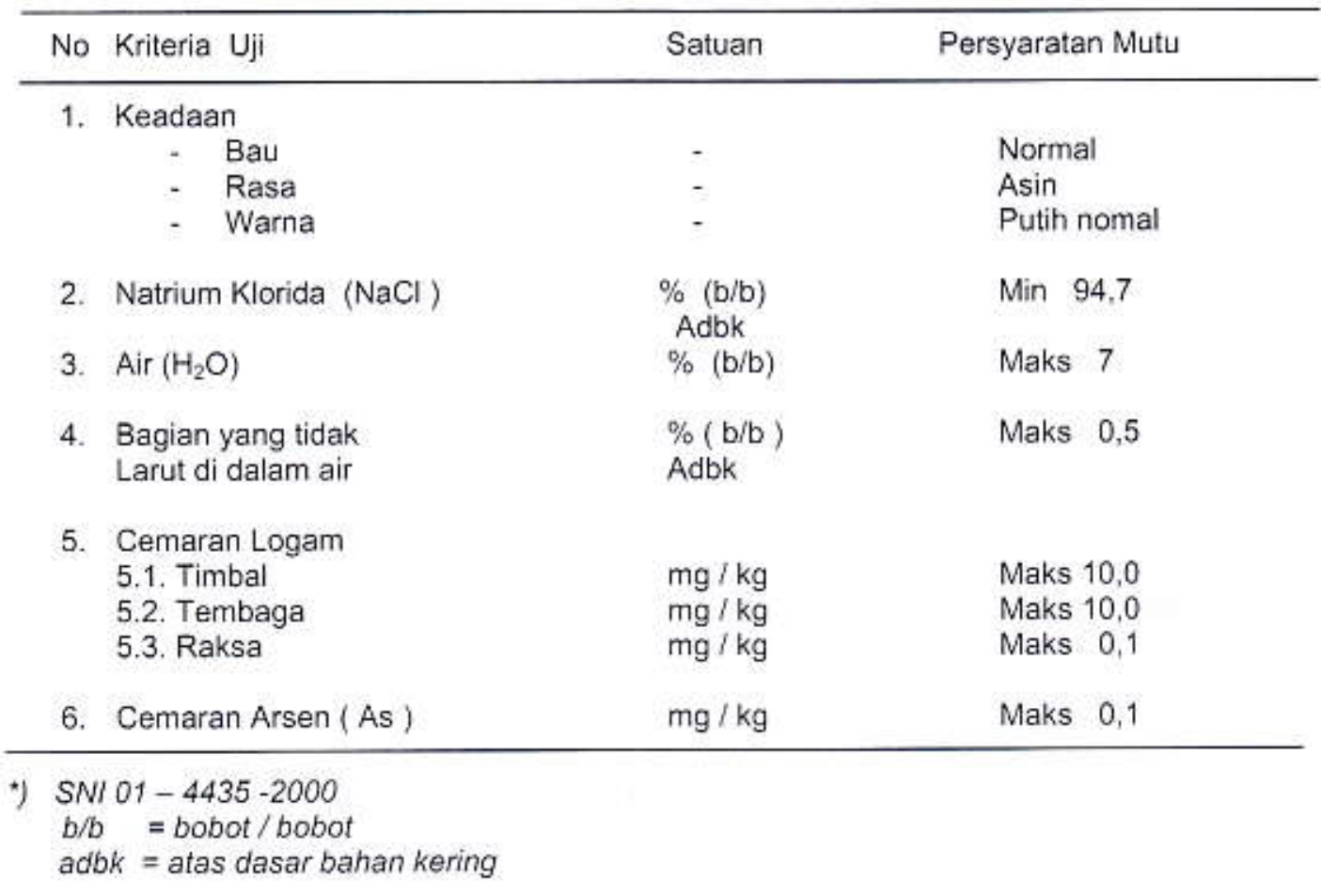

Kondisi bahan baku yaitu garam rakyat mutunya sangat bervariasi dan biasanya masih belum memenuhi standar yang ditentukan, baik kenampakan (warna) maupun kadar garamnya $(\mathrm{NaCl})$. Oleh sebab itu, untuk mendapatkan mutu garam bahan baku sesuai SNI tersebut, terutama kadar warna dan kadar $\mathrm{NaCl}$ proses yang harus dilakukan adalah pencucian yang dilakukan di sentra produksi atau di luar sentra produksi.

Pencucian dilakukan untuk mengurangi ion $\mathrm{Ca}^{++}, \mathrm{Mg}^{++}$dan $\mathrm{SO}_{4}{ }^{2 *}$ serta kotoran lainnya yang terdapat dalam garam. Pencucian dengan menggunakan larutan air jenuh garam (brine) yang bersih dengan konsentrasi $20-25^{\circ} \mathrm{Be}$ dan kandungan $\mathrm{Mg}$ tidak lebih besar dari $10 \mathrm{mg} / \mathrm{l}$, dapat mengendapkan zat-zat yang mengotorinya sehingga warna garam lebih putih dan kadar NaClnya lebih tinggi (BPPI Semarang 1984).

Proses pencucian yang dilakukan di luar sentra dapat dilakukan oleh perusahaan garam yang mempunyai izin pencucian garam dan mempunyai peralatan pencucian garam yang terpasang. Peralatan proses pencucian garam yang digunakan meliputi bakbak pencucian, bak pencampuran (mixing chamber) alat pengaduk dan pompa (mixing pump) (Dep. Perindustrian, 2005).

Proses selanjutnya adalah proses pengolahan garam konsumsi beryodium di pabrik (industri) garam, yang terdiri dari proses pengeringan, penggilingan, penyemprotan yodium, pengemasan dan pelabelan. Proses pengeringan wajib dilakukan terhadap garam yang telah dicuci agar kadar air maksimum $7 \%$ (b/b). Peralatan pengeringan dapat berupa alat pengering putar (centrifuge), pengering temperatur tinggi (dryer) atau lemari pengering (oven). Suhu pengeringan $105-150^{\circ} \mathrm{C}$ selama $20-30$ menit. Penggilingan dilakukan dengan mesin giling yang menghasilkan besaran garam 16 - 18 mesh, sesuai dengan standar perusahaan. Setelah halus dicampur dengan yodium dengan cara disemprot melalui ban berjalan atau belt conveyor, kemudian dikemas dan diberi label. ( Dep. Perindustrian RI, 2005).

Produk garam konsumsi beryodium yang diperoleh di wajibkan menggunakan tanda SNI 01 - 3556 - 2000 pada saat dipasarkan. Tanda SNI tersebut dapat diberikan jika perusahan telah memenuhi syarat manajemen mutu dan produknya memenuhi syarat tersebut dapat dilakukan pada Tabel 2. 
Tabel 2. Syarat Mutu Garam Konsumsi Beryodium *)

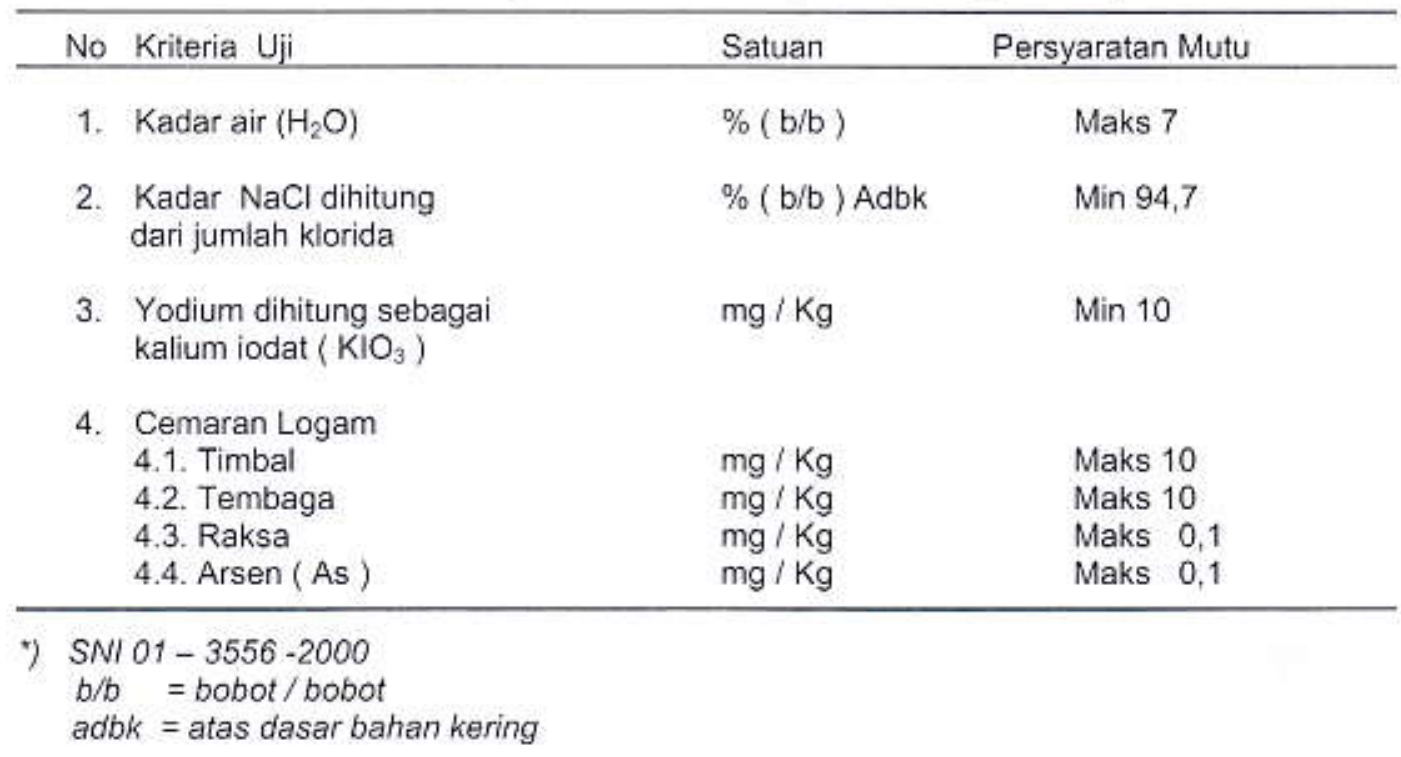

\section{APLIKASI GMP PADA INDUSTRI GARAM KONSUMSI BERYODIUM}

Untuk menghasilkan produk akhir yang memenuhi standar dan dijamin keamanan produknya. Penerapan GMP pada industri garam konsumsi beryodium harus memperhatikan aspek-aspek seperti yang tercantum dalam SK. Menteri Kesehatan No. 23/Men. Kes/SK/1978.

Penerapan aspek-aspek tersebut di industri garam konsumsi akan dibahas dalam bab ini.

\section{Lokasi Pabrik}

Lokasi pabrik findustri mempunyai pengaruh langsung pada sanitasi, terutama dengan kebersihan lingkungan dan pelayanan. Lingkungan yang kotor dan tidak tersedia sarana pembuangan akan merupakan sumber pencemaran serta menyulitkan sanitasi ( Winarno, 2004)

Pada industri pengolahan garam konsumsi beryodium, sebaiknya jauh dari pemukiman penduduk, karena akan mengurangi pencemaran dari lingkungan sekitar. Dilokasi pabrik, perlu diperhatikan selokan dan sarana pembuangan sampah. Diusahakan pembersihan genangan selokan dan tempat sampah sesering mungkin. karena untuk menghindari kontaminasi serangga, jasad renik dan hewan pengerat.

\section{Bangunan}

Rencana konstruksi dan tata letak bangunan memegang peranan penting. Hal tersebut berpengaruh pada usaha menciptakan kondisi sanitasi dan memudahkan tindakan sanitasi yang diambil. Dalam hal ini bangunan memenuhi persyaratan teknik dan higiene produk yang diproduksi, mudah dibersihkan dan dilaksanakan tindakan sanitasi dalam mempertimbangkan sirkulasi udara, cahaya, serta ruang gerak yang cukup ( Winarno, 2004 ).

Bangunan untuk industri pengolahan garam konsumsi beryodium harus dibuat berdasarkan perencanaan yang memenuhi persyaratan teknik dan higiene produk garam konsumsi beryodium, sehingga mudah dibersihkan dan dilakukan tindakan sanitasi. Ruangan dalam pabrik garam konsumsi beryodium terdiri dari ruangan produksi, ruangan penyimpanan (gudang) bahan baku dan produk, laboratorium penguji dan ruangan administrasi. Dalam lingkungan pabrik, antara ruangan yang satu dengan yang lain mempunyai kesinambungan, sehingga tidak hanya ruang pengolahan saja yang perlu dijaga kebersihannya tetapi ruangan yang lain perlu diperhatikan juga. 
Lantai ruang produksi harus tahan terhadap air dan garam, tidak mudah rusak dan mudah dibersihkan. Sebaiknya lantai ruangan dibersihkan setiap hari dengan air yang dicampur cairan pembersih. Begitu juga dinding pintu dan jendela ruangan mempunyai syarat yang sama dengan lantai. Atap dan langit-langit juga dibersihkan secara periodik. Keduanya tidak boleh retak dan ada bagian yang terlepas.

\section{Peralatan}

Peralatan yang kontak langsung dengan makanan, merupakan sumber cemaran baik fisik, kimia maupun mikrobiologi. Ketiga bahaya tersebut antara lain jasad renik, logam yang lepas, minyak pelumas, bahan bakar dan lain-lain. Agar alat mudah dibersihkan, sebaiknya terbuat dari bahan yang tahan karat, mudah dibongkar pasang dan mudah pengoperasiannya ( Winarno, 2004).

Pada industri garam konsumsi beryodium, alat-alat yang digunakan sebaiknya tahan terhadap garam, tidak mudah berkarat dan mudah dibersihkan, terutama alat yang kontak langsung dengan garam.

Alat-alat pada pabrik pengolahan garam konsumsi beryodium adalah oven pengering berupa lemari atau bak, alat penggiling, bak penampung garam halus, belt conveyor, alat penyemprot, alat pengaduk dan alat pengemas. Sanitasi merupakan bagian penting dari peralatan yang digunakan dalam proses produksi di pabrik makanan, karena sanitasi peralatan yang kurang dapat menyebabkan peralatan tersebut menjadi media yang baik bagi pertumbuhan mikroorganisme.

Oleh karena itu perlu dilakukan pencucian peralatan yang digunakan dalam proses produksi. Pencucian dilakukan pada saat peralatan akan digunakan, sehingga bila ada selang waktu peralatan tidak digunakan, maka harus dilakukan pencucian sebelum digunakan kembali. Pencucian dilakukan dengan menggunakan larutan detergen sebagai pembersih dan anti septik.

\section{Fasilitas Sanitasi}

Untuk menciptakan sanitasi yang baik, harus didukung fasilitas, seperti sarana penyediaan air bersih, fasilitas higiene karyawan, ventilasi, alat untuk sanitasi (alatalat pembersih) dan lain-lain. Sarana penyediaan air harus dapat menyediakan air yang cukup bersih untuk produksi dan rumah tangga perusahaan.

Disamping itu bangunan harus dilengkapi dengan sarana pembuangan untuk buangan padatan dan cairan. Fasilitas higiene karyawan berupa sarana toilet serta dilengkapi dengan fasilitas cuci tangan yang ditempatkan pada tempat yang strategis.

\section{Bahan}

Bahan baku dan bahan tambahan yang digunakan untuk proses pembuatan produk tidak boleh merugikan. Oleh karena itu harus ada suatu sistem jaminan mutu, dalam rangka penerapan standar tertentu. Untuk memenuhi hal tersebut harus dianalisa secara organoleptik, kimia, fisik, biologi dan mikrobiologi (Winarno, 2004) Pada industri pengolahan garam konsumsi beryodium, bahan baku yang diperoleh dari pemasok (sub kontraktor) harus diperiksa fisiknya secara visual pada saat diterima. Bila terjadi ketidaksesuaian dari hasil pemeriksaan harus ditindak lanjuti, sedangkan bila lulus, langsung diterimakan dan dimasukkan kedalam ruangan penyimpanan bahan baku. Dari sub kontraktor juga harus dimintakan hasil uji bahan baku garam yang memenuhi syarat mutu Garam Bahan Baku untuk Industri Garam Beryodium ( SNI 01-4435-2000).

Bahan penolong untuk industri garam konsumsi beryodium adalah Kalium lodat dibeli berdasarkan atas mutu produk yang ditentukan ketika Kalium lodat diterima di perusahan diperiksa mutunya. Barang yang memenuhi persyaratan disimpan dalam gudang penyimpanan. 


\section{Higiene Karyawan}

Karyawan berhubungan langsung dengan bahan baku maupun produk. Oleh karena itu karyawan punya potensi besar untuk mencemari produk. Kontaminasi dapat secara langsung maupun tidak langsung, jadi karyawan menjadi subyek dari pelaksanaan sanitasi di industri.

Perusahan sebaiknya menciptakan keadaan lingkungan kerja yang aman, bebas dari kecelakaan dan bersih, serta senantiasa memberikan penyuluhan tentang pentingnya suatu sanitasi kepada pekerja. Para karyawan berkewajiban mentaati dan mematuhi ketentuan-ketentuan kerja yang diterapkan.

Dalam hal ini perusahaan memberikan fasilitas untuk menjaga sanitasi, antara lain pakaian kerja berupa seragam, sepatu bot di bagian produksi, tutup kepala dan lain-lain. Di perusahaan garam konsumsi beryodium, proses yang mempunyai potensi kontak langsung dengan karyawan adalah pada saat pengadukan dan pengangkutan garam dari bak setelah penyemprotan ke tempat pengemasan serta proses pengemasan. Oleh sebab itu, pada bagian tersebut sebaiknya karyawan menggunakan tutup kepala, mencuci tangan dahulu sebelum bekerja dan tidak diperbolehkan merokok di ruang produksi.

\section{Pengendalian Proses Pengolahan}

Tindakan pengendalian ini bertujuan memproduksi makanan yang bermutu, terutama mengurangi produk cacat, rusak atau tidak memenuhi standar. Pada proses pengolahan garam konsumsi beryodium, pengendalian dilakukan sejak penerimaan bahan baku, proses produksi yang meliputi pengeringan, penggilingan dan penyemprotan yodium serta proses pengemasan produksi ( Sudibyo, 2008).

Pada proses pengeringan, garam bahan baku dikeringkan pada suhu $105-115^{\circ} \mathrm{C}$ selama 30 menit. Sedangkan penggilingan garam dilakukan dengan mesin giling menghasilkan besaran garam 16-18 mesh. Proses selanjutnya adalah penyemprotan yodium dengan cara disemprot pada garam di belt conveyor, perbandingan larutan yodium adalah 200 gram yodium dalam 10 liter air bersih dengan menggunakan alat yodisasi (Sudibyo, 2008).

Pengendalian proses pengolahan dilakukan dengan cara menyediakan instruksi kerja yang rinci, menyediakan peralatan proses produksi yang sesuai dengan tahapan proses produksi garam, termasuk pemeliharaan mesin yang digunakan dan melakukan inspeksi/pengujian selama proses.

Pengujian yang dilakukan adalah pengujian secara visual terhadap kadar air garam bahan baku sampai pemeriksaan kandungan yodium setelah disemprot. Untuk pengujian yang tidak memenuhi syarat, bagian produksi perlu melakukan tindakan perbaikan.

\section{Produk Akhir}

Produk akhir perlu dianalisa mutunya, sesuai dengan standar yang berlaku. Untuk produk garam konsumsi beryodium, analisis yang perlu dilakukan setiap kali produksi adalah kandungan yodium pada garam, yaitu harus memenuhi standar SNI01-3556-2000, sebesar minimum $30 \mathrm{ppm}(30 \mathrm{mg} / \mathrm{kg}$ ). Produk yang telah memenuhi syarat dipisahkan dengan produk yang tidak memenuhi syarat pada saat penyimpanan digudang produk, dan sebaiknya diberi tanda. Untuk parameterparameter lain, produk garam konsumsi yodium dapat diujikan secara periodik ke laboratorium di luar perusahaan.

\section{Bahan Kemasan}

Bahan dari kemasan berfungsi utama untuk melindungi produk, baik yang bersifat primer maupun sekunder. Untuk memenuhi fungsi tersebut, bahan tidak bersifat mencemari produk. Oleh karena itu perlu dipertimbangkan jenis bahan kemasannya. 
Menurut peraturan Men Perin. RI No 42/ M-IN/Per/ll/2005 Tanggal 29 November 2005 , bahan kemasan produk garam konsumsi beryodium untuk isi bersih $50 \mathrm{~kg}$ dan $25 \mathrm{~kg}$ adalah karung plastik jenis poly-propylene (PP) yang bagian dalamnya dilapisi dengan kantong plastik warna dasar putih. Sedangkan kemasan untuk isi bersih $5 \mathrm{~kg}$, $1 \mathrm{~kg}, 500$ gram, 250 gram dan 100 gram adalah plastik poly propylene (PP) atau poly ethylene (PE) dengan ketebalan minimum $0,5 \mathrm{~mm}$.

10. Label

Spesifikasi dari produk tercantum pada label kemasan. Pada label ini memuat keterangan produk. Label juga dapat berfungsi untuk menarik konsumen pada label kemasan garam konsumsi beryodium, harus memuat keterangan yang jelas, yaitu :

- Tulisan "Garam Konsumsi Beryodium"

Kandungan kalium iodat $\left(\mathrm{KIO}_{3}\right)$ minimal $30 \mathrm{ppm}$

Berat bersih

- Tanda / logo SNI

- Nomor Pendaftaran dari Badan POM

- Komposisi isi Garam Konsumsi

Merk Dagang

- Nama dan Alamat Perusahaan

- Pada kemasan garam bahan baku harus ditulis dengan jelas, berupa :

- Tulisan "Garam Bahan Baku"

- Berat Bersih

- Nama dan Alamat Perusahaan

- Untuk garam bahan baku yang belum dicuci, tambah keterangan berupa tulisan "Garam Baku Belum Dicuci" (Dep. Perindustrian, 2005).

\section{Penyimpanan}

Kondisi penyimpanan bahan baku, bahan penolong dan produk akhir harus diperhatikan perencanaan, desain dan implementasi dari penyimpanan menentukan tingkat keefektifannya. Dengan sistem manajemen yang baik, bahan yang disimpan tidak akan mudah rusak.

Dalam penyimpanan, bahan baku, bahan penolong dan produk akhir harus ditandai dan ditempatkan sedemikian rupa hingga jelas dibedakan antara yang belum diperiksa dan yang sudah diperiksa, jelas dibedakan antara yang memenuhi persyaratan dan yang tidak memenuhi persyaratan, bahan yang terdahulu diterima digunakan terlebih dahulu, produk akhir yang terdahulu dibuat diedarkan terlebih dahulu (Dep.Kesehatan, 1978).

Bahan berbahaya seperti desinfektan, inseksida, rodentisida, bahan bakar dan bahan yang mudah meledak harus disimpan dalam ruangan tersendiri sehingga tidak mencemari bahan baku, bahan penolong dan produk akhir, wadah, label dan alat perlengkapan produksi harus disimpan dengan baik dan terlindung dari debu dan pencemaran lain (Dep. Kesehatan, 1978).

\section{Pemeliharaan Sarana Pengolahan dan Kegiatan Sanitasi}

Pemeliharaan sarana pengolahan dan kegiatan sanitasi bertujuan untuk menjamin pabrik dan produk bebas dari cemaran fisik, kimia, biologi dan mikrobiologi. Pemeliharaan meliputi pemeliharaan bangunan dan peralatan produksi. Pemeliharaan bangunan dan lokasi pabrik berupa pemeliharaan secara teratur dan berkala yaitu pembersihan, pencegahan masuknya binatang pengerat, serangga dan lain-lain. 


\section{PERMASALAHAN-PERMASALAHAN DALAM APLIKASI GMP DI INDUSTRI GARAM KONSUMSI BERYODIUM SKALA UKM}

\section{Bangunan dan Peralatan}

Industri garam di Indonesia saat ini sebagian besar dilakukan oleh industri berskala UKM. Oleh sebab itu bangunan umumnya masih sederhana dan peralatannya menggunakan teknologi sederhana pula.

Permasalahan yang sering timbul di industri garam dalam aplikasi GMP adalah pada aspek bangunan dan peralatan. Pada aspek bangunan, permasalahannya adalah pemilihan lantai yang tahan terhadap air dan garam. Pada aplikasi GMP lantai harus rapat air dan tahan terhadap air, garam, basa, asam atau bahan kimia lainnya. Permukaan harus rata, halus tapi tidak licin dan mudah dibersihkan.

Garam bersifat higroskopis atau menyerap air, oleh sebab itu umumnya industri garam kesulitan memilih lantai yang sesuai. Jika digunakan lantai dari keramik diruang produksi, lantai licin karena air yang timbul dari pengolahan garam, sehingga dapat membahayakan. Untuk mengatasi hal itu sebaiknya dipilih lantai dari semen karena permukaannya tidak licin dan tahan air.

Peralatan yang digunakan di industri garam sesuai dengan aspek peralatan pada aplikasi GMP yaitu peralatan yang sesuai dengan jenis produk yang dihasilkan. Permasalahan yang sering timbul adalah timbulnya karat pada alat penggiling yang terbuat dari logam. Pada UKM industri garam, umumnya alat penggiling masih sederhana, sedangkan di industri besar, peralatan terbuat dari stainless steel. Untuk mengatasi hal tersebut, pada UKM yang masih menggunakan peralatan sederhana perlu pemeliharaan peralatan secara kontinyu sehingga proses perkaratan dapat dicegah.

\section{Proses Pengolahan}

Aspek pengolahan garam konsumsi beryodium yang cukup penting dan sering menimbulkan masalah adalah proses penyemprotan kalium iodat. Permasalahannya adalah kurang meratanya kandungan kalium iodat pada produk garam konsumsi beryodium.

Faktor yang mempengaruhi proses penyemprotan Kalium lodat adalah penentuan konsentrasi Kalium lodat dan alat penyemprot yang digunakan. Dalam aplikasi GMP, tahapan proses pengolahan sangat penting, terutama yang mempengaruhi mutu produk.

Untuk mengatasi hal tersebut, perlu dibuat rencana produksi yang benar yaitu perencanaan dan percobaan-percobaan penentuan konsentrasi Kalium lodat agar dihasilkan produk garam konsumsi beryodium berkadar yodium minimal 30 ppm. Disamping itu perlu dipilih peralatan penyemprotan yang tepat (spray mixing system) (Dep. Perindustrian, 2005).

\section{Bahan Kemasan}

Permasalahan yang sering timbul di industri garam skala UKM pada aspek bahan kemasan adalah digunakannya plastik dengan ketebalan kurang dari 0,5 $\mathrm{mm}$. Hal ini terjadi karena harga plastik kurang dari $0,5 \mathrm{~mm}$ lebih murah dari plastik PP atau PE $05 \mathrm{~mm}$. Untuk mengatasi hal itu, perlu ada sosialisasi dari instansi terkait tentang peraturan Men. Perin. RI No 42/M-IN/Per/l/2005 yang berisi peraturan penggunaan kemasan yang sesuai untuk produk garam konsumsi beryodium.

\section{KESIMPULAN}

Aspek-aspek GMP seperti lokasi, bangunan, fasilitas sanitasi, alat produksi, bahan, proses pengolahan, produk akhir, higiene karyawan, bahan kemasan, label, penyimpanan dan pemeliharaan dapat diaplikasikan di industri pengolahan garam 
konsumsi beryodium. Dengan penerapan GMP ini, proses produksi yang aman telah dilaksanakan untuk menghasilkan produk pangan dengan mutu yang diharapkan.

Sistem pengendalian mutu dan penerapan GMP perlu dimasyarakatkan kepada para pemilik / penanggung jawab industri garam konsumsi beryodium, untuk menjamin bahwa produk yang dihasilkan aman untuk dikonsumsi dan memenuhi syarat SNI 01 3556-2000. Sosialisasi tersebut hendaknya disampaikan dengan cara yang sederhana dan mudah dipahami, karena sebagian besar industri garam konsumsi beryodium adalah UKM.

\section{DAFTAR PUSTAKA}

Badan Standardisasi Nasional (BSN). 2000. Standar Nasional Indonesia (SN) 01-35562000 Garam Konsumsi Beryodium. Badan Standardisasi Nasional. Jakarta.

Badan Standardisasi Nasional (BSN). 2000. Standar Nasional Indonesia (SNI) 01-44352000 Garam Bahan Baku. Badan Standardisasi Nasional. Jakarta.

Berita Aqrokim. 2008. Garam dan Industri Garam Indonesia. http ://ikah.depperin.qo.id/queri/info.php?action=view \& info id=25. (akses 22/01/2008).

BPPI Semarang. 1984. Stabilisasi Yodat dalam Garam Konsumsi. Balai Penelitian dan Pengembangan Industri Semarang. Semarang.

BPPI Semarang. 1985. Laporan Penelitian Peningkatan Teknologi Proses Pengolahan Garam Rakyat Menjadi Garam Industri dengan Tenaga Surya. Balai Penelitian dan Pengembangan Industri Semarang. Semarang.

BPPI Banjarbaru. 1989. Usaha Peningkatan Mutu Garam Konsumsi Beryodium. Balai Penelitian dan Pengembangan Industri Banjarbaru. Banjarbaru

BPPI Pontianak. 2001. Uji Coba Proses Pengolahan Garam Rakyat Di Kampung Sintang. Balai Penelitian dan Pengembangan Industri Pontianak. Pontianak.

Departemen Kesehatan. 1978. Kep. Menteri Kesehatan RI No 23/MEN.KES/SK/1978 Tanggal 24Januari 1978 Tentang Pedoman Cara Produksi yang Baik Untuk Makanan. Dep. Kesehatan. Jakarta.

Departemen Perindustrian. 1995. SK.Menteri Perindustrian RI No 23/MEN. Kes/SK/2/1995 Tanggal 16 Februari 1995 Tentang Pengesahan Serta Penerapan Standar Nasional Indonesia dan Penggunaan Tanda SNI secara Wajib terhadap 10 (sepuluh) Macam Produk Industri. Dep. Perindustrian. Jakarta.

Departemen Perindustrian. 2005. Peraturan Men. Perindustrian RI No 42/MIND/PER/II/2005. Tentang Pengolahan, Pengemasan dan Pelabelan Garam Beryodium. Dep. Perindustrian. Jakarta.

Prasetyo, B.N, Djoko Wilaiso, Sigit K, Ag.S Nur Widiawati. S. Raharjo.Suparno, Suyono. 1997. Prototipe Alat Washing Garam untuk Skala Industri Garam Rakyat. BPPI Semarang. Semarang.

Sudibyo, A. 2008. Teknologi dan Pengendalian Mutu Pengolahan Garam. BBIA. Bogor. 
Thaheer. H. 2005. Sistem Manajemen HACCP. Bumi Aksara. Jakarta.

Winarno, F.G dan Surono. 2004. GMP Cara Pengolahan Pangan yang Baik. M-Brio Press cetakan 2. Bogor. 